\title{
Contested terrains within the neo-liberal project
}

\section{The re-organisation of services for children in Europe: gender, citizenship and the forging of New Public Management within professional child care social work practice in Europe}

\author{
Marion Ellison \\ Queen Margaret University, Edinburgh, UK
}

\begin{abstract}
Purpose - This paper sets out to explore the relationship between gender, New Public Management (NPM), citizenship and professional and user group identities and relationships within child care social work practice.

Design/methodology/approach - The paper utilises findings from a major comparative survey undertaken in Denmark and the UK as part of Doctoral research. In addition the paper draws upon more recent empirical research carried out by the author in Sweden.

Findings - Paradigms imported from the private sector have led to the adoption of NPM, fiscal austerity and the reorganisation of childcare social work throughout Europe. This paper illustrates the connectivities between NPM, gender, citizenship and the contested terrains within which professional and user group relationships and identities are being forged. The paper offers a unique insight into the operationalisation of NPM and gender within childcare professional social work practice in different European settings.

Research limitations/implications - The paper's findings may be used to contribute to existing theoretical and empirical knowledge within the field of professional childcare social work and practice.

Originality/value - The paper offers a unique insight into the operationalisation of gender equality as a normative ideal premised on the development of organisational and legal settings which embrace an awareness of the duality of public and private spheres and the impact of different European welfare settings on the articulations of notions of gender and citizenship, which in turn operationalise processes of inclusion and exclusion of women as citizens, workers and parents.
\end{abstract}

Keywords Gender, Citizenship, Child care, Social workers, Europe

Paper type Conceptual paper

\section{Preamble}

This paper explores the relationship between gender, New Public Management (NPM), citizenship and professional and user group identities and relationships within child care social work practice. The paper utilises findings from a major comparative survey undertaken in Denmark and the UK as part of Doctoral research. In addition the paper draws upon more recent empirical research carried out by the author in Sweden. Paradigms imported from the private sector have led to the adoption of NPM, fiscal austerity and the reorganisation of child care social work throughout Europe. This paper illustrates the connectivites between NPM, gender, citizenship and the "contested terrains" within which professional and user group relationships and identities are being "forged" (Barry et al., 2003). The paper's findings may be used to contribute to existing theoretical and empirical knowledge within the field of professional child care social work and practice. The paper offers a unique insight into the operationalisation

Equal Opportunities International Vol. 26 No. 4, 2007 pp. $331-351$

Emerald Group Publishing Limited 0261-0159

DOI $10.1108 / 02610150710749430$ 
EOI

26,4

332 of NPM and gender within child care professional social work practice in different European welfare settings.

\section{Introduction}

Neo-liberalism, NPM and gender within child care social work in Europe

Neo-liberal economic ideology is based upon the belief that exchange within the market economy offers an ethical basis for all human action (Harvey, 2005). Neo-liberalism articulates the value of unregulated trade and markets within a global economic framework. Influencing political thought and policy since the 1970s, neo-liberalism places market processes, finance and privatization, at the centre of state power and intervention within the public welfare sphere. (Rhodes, 1996; Beresford 2005). Whilst State interventions in the economy are discouraged, state obligation for the welfare of its citizens is reduced. (Lorenz, 2001; Andersen and Guillemard, 2006). The neo-liberal economic agenda in Europe has been couched in a way which has assumed the inevitability of the re-defining of public welfare boundaries (Mishra, 1999). The perception of neo-liberalism as having a harmful effect on the organization, funding and legitimation of welfare is articulated by a growing body of theoretical and empirical work in this field, often fitting new conceptualisations of democracy to the changing circumstances of global economics (Andersen and Guillemard, 2006; Lorenz, 2001; Pugh and Gould, 2000; Trevellion, 1997). The contested nature of this view is amplified by writers such as Deacon (2001) who argues that neo-liberalism and globalisation offer the possibility of the creation of a new global social policy. Earlier assessments argued that neo-liberalism de-stabilizes economic and social organisation in society, (Navarro, 1998; Rhodes, 1996; Trevellion, 1997). Offe (1996) and Lorenz (2001), further emphasized the effects of neo-liberalism by finding that the erosion of existing arrangements for welfare was growing rapidly. Moreover, economic and social dis-welfares arising from changes in the organisation of production and consumption increase the need for welfare, while at the same time emphasizing the need to reduce the resources available to meet these needs (Sykes et al., 2005; Andersen and Guillemard, 2006). and Gould Pugh (2000) remind us that the rationale of global neoliberal economics with the focus on free-market values destroys the humanistic value-base of social work rendering traditional paradigms of professional social work unsustainable, particularly in relation to the protection of human rights and social inclusion. Neo-liberal economic policies are being implemented within the public sector largely through NPM (Sykes et al., 2005; Andersen and Guillemard, 2006; Lorenz, 2001; Clarke, 2005). Here, two key interdependent strands have emerged. Firstly, changes in strategies of governance have emerged in a paradigm imported from the private sector. The fragmentation of the public domain and transformations within civil society has elevated the significance of these new forms of governance (Born and Jensen, 2005; Clarke and Newman, 1997; Clarke, 2005). As Kooiman (1993) argues, the purpose of national governments is no longer about formulating public policy but rather to guide and influence. This is reinforced by Newman (2003) who argues that:

The power of the nation state has been eroded and governance processes are now characterised by multi-level interactions between different tiers within and beyond the nation state (Newman, 2003, p. 6).

Here state-society interactions are underpinned by "co" arrangements which involve co-governing. Public services are no longer governed within economic structures or processes but are managed within citizenship models, concepts of community and 
social and cultural formations (Saks, 1999; Born and Jensen, 2005; Clarke and Newman, 1997). A second strand is the imposition of fiscal austerity. Resources are distributed according to a new agenda which stresses that social justice is no longer about equality of outcome; standards have become the key phrase and rights are balanced by obligations (Lorenz, 2001; Andersen and Guillemard, 2006). There are different approaches to the pervasiveness and dominance of neo-liberalism. Clarke (2005) offers an optimistic view arguing that there are "active political and cultural discourses around which people mobilise, organise and act” (p. 22). Further, Newman (2003) reveals that dilemmas experienced by public service managers in England encountering NPM were "personal" but "rooted in wider structural tensions and governance shifts" (Newman, 2003, p. 6). The emergence of contestation, blockages and resistance within these contested terrains has been evidenced by a number of authors (Clarke, 2005; Newman, 2003; Larsen, 2005; Mooney and Poole, 2004. Clarke (2004) argues that the successful implementation of neo-liberal strategies in the UK requires the liberation of "active subjects (individuals and corporations) from past to future." Here consumers, as responsible parents and active citizens, need to overcome the blockages and inhibitions to being modern (Clarke, 2004, p. 42). This paper focuses on the exploration of blockages to the imposition of NPM within public sector childcare social work professional practice and explores connectivities between childcare social work practice, gender, citizenship and governance within different European settings. Centrally, how do looked-after children, their families and welfare professionals come to understand and experience NPM within practice. When we explore identity we explore not only life narratives and meanings we also explore personal and professional identity as it is constituted through the models of citizenship and needsbased and rights-based policy frameworks. The paper utilises case study and interview extracts to illustrate these connectivities, focusing upon the impact and implications of gender on the implementation of NPM strategies within child care social work practice. The analysis of these connectivities is theoretically premised on NMP as a "contested terrain" (Barry et al., 2003). Here it is argued that the reconfiguration of management/professional relations is cascaded down to the implementation of NPM at practice level reconfigurinprofessional/user group relations. The paper encourages further comparative research to illuminate the way in which NPM is forged when implemented within practice environments within different national settings. Such research would contribute to social work theory and practice development.

Contested terrains; child care social work in Europe; Why national setting matters: governance, citizenship, NPM and gender

Child care social work, theory, practice and methodology in Europe is unified by principles which articulate the importance of prevention, ecological approaches, the maintenance of family ties and partnership between professionals and user groups (Lorenz, 2006; Hellinkxz and Colton, 1998; Munday and Ely, 1996; Acker, 1990; Orloff, 1993; Jack, 2000). Legitimized by international rights conventions such as the United Nations Rights of the Child, these principles are embedded in child care laws across European settings. The translation of these principles into practice is dependent upon specific cultural, political and organisational factors (Lorenz, 2006; Ellison and Haestback, 1998). When examined more closely, however, decision-making processes within child care social work are also reliant upon a complex interplay involving governance, citizenship and gender. A burgeoning body of theoretical and empirical
Re-organisation of services for children

333 
EOI

26,4

334 research has explored state social provision as it affects the material situation of women, shapes gender relationships, structures political conflict and partipation and contribues to the formation and mobilaation of identies and interests (Lister, 2006; Baines, 2004; Barry et al., 2003; Ungerson, 1990; Ely, 1995). Whilst this paper contributes to this body of research its main concern is to explore connectivities between child care social work practice, gender, citizenship and governance within different European settings. The paper utilises case study and interview extracts to illustrate these connectivities, focusing upon the impact and implications of gender on the implementation of NPM strategies within child care social work practice. How gender actually operates within practice with looked-after children and their parents is of central concern here. Here, the import of wider factors particularly modes of citizenship are considered. The analysis of these connectivities is theoretically premised on the NMP as a "contested terrain" (Barry et al., 2003). It is argued that the reconfiguration of management/professional relations at operational levels cascades down to the implementation of NPM at practice level forging the reconfiguration of professional and user group relations. The implementation of NPM within practice environments involves a contested terrain affected by the interplay of a plethora of variables including meanings and perceptions at the level of self in the form of life histories and narratives, gender, modes of citizenship, structural inequalities, needs led and rights led approaches to social policy and social work theory and methodology (Ellison, 2003; Ellison and Hestbaek, 1998; Garratt, 2002). The paper does not propose to offer an exhausitive account of these contested terrains and connectives but rather to offer some illustrations of them. The paper encourages further comparative research to illuminate the way in which NPM is forged within practice environments within different national settings. Such research would contribute to social work theory and practice development. The organisational restructuring of child and welfare services in England and Wales may be used to exemplify this approach. The Every Child Matters Green Paper (2003) and subsequent Children Act 2004 (England and Wales) have resulted in the combining of Education and Social Care functions. The commission for social care inspection has been subsumed into Ofsted highlighting the takeover of social care by education. The splitting of children's services from services for families has undermined holistic approaches within social work practice. The ramifications of this at a resource level are self-evident. However, the separation of services has more potent implications for the well being of looked-after children and their families. Primarily, decision-making processes within care planning become fragmented as the relationship between the state and the family becomes one in which the education of the child, not the welfare of the family is placed at the forefront. As Lister (2006) has argued this has been located within a paradigm of gendered citizenship where children are defined as a future investment, rather than current beings. Parents are there to facilitate this investment and they matter in so much as they function to fulfill this obligation (Lister, 2006). In contrast, citizenship within the Scandinavian model (Sweden, Denmark, Finland and Norway) is characterized by a focus on citizenship rights and individual entitlements available to all (Lorenz, 2006; Andersen and Guillemard, 2006; Hellinkxz and Colton, 1998; Trevellion, 1997). Autonomy is an important factor driving policy in these countries. A key consequence of this is that there are fairly high levels of gender equality (Andersen and Guillemard, 2006). The Gender Equality Law in Denmark (2002) makes this explicit.

2.2a (2) Indirect discrimination means that a provision, a criterion or a practice, which seems to be neutral, places a considerably larger number of persons of one gender in an inferior 
position compared with the other gender. (Gender Equality Consolidation Act 2002, Danish Ministry of Social Affairs).

Here, it may be argued that integrated child and family policies in Denmark mitigate the prospect of the indirect discrimination suffered by mothers of looked-after children. An important caveat to this lies in research evidence that has uncovered the propensity welfare workers in Denmark and Sweden to focus their main interest on the mother's capability (Anderson, 1995; Ellison, 2000). In addition most studies relating to the epidemiology of foster care in Sweden and Denmark have uncovered evidence that the majority of children in foster care in these countries have single mothers and absent fathers (Egelund, 1996; Ellison, 1999). These trends, replicated in the UK (Ryburn, 1996) are indicators of the extent of social exclusion and marginalization experienced by single mothers in Sweden, Denmark and the UK. Despite these commonalities, recent comparative research has revealed the importance of the way in which welfare legislation is constructed within different welfare settings (Andersen and Guillemard, 2006; Hellinkxz and Colton, 1998; Ellison and Dorthe-Hestbaek, 1998) Thus, in Sweden and Denmark services are constructed according to peoples' rights, care is individualized according to the continuity principle; this results in whole families entering care. Here, dual socialization, the notion that the state is as responsible as the parent for the upbringing of the child, is a central driving mechanism (Mehlbye, 1993). This paper will argue that these differences impact significantly on the way in which NPM is forged within the practice environment of national welfare settings within Europe.

\section{What does this mean for practice?}

The concept of "partnership" is a central point of convergence in child care law across Europe. The relationship between professionals and user groups within care planning for looked-after children is based on the legal and theoretical precept of partnership. Yet, on closer inspection when we contextualize notions of partnership within different welfare settings the micropolitics of professional user relationships is itself inextricably connected with wider political and professional discourses which define the rationale of state interventions in families' lives (Harding, 1991). As mediators of this rationale Child welfare professionals articulate wider connectivities between the state, children and their families (Lister, 2006; Lorenz, 2006; Parton, 1991). Contextualizing child welfare practices within legal, political and professional paradigms problematises the basic norms, which rationalise legal, political and professional discourses. This paper argues that, in functioning as the axis of this normative relationship, models of citizenship define and regulate the dynamics of child welfare practice. Child welfare professionals are encharged with the dual task of mediating NPM within child care social work whilst reconciling their own professional and personal identities, values, meanings and ethics. Indicators of contestation and blockages at strategic and operational levels reveal the way in which NPM is being modified by political, professional and user discourses, actions and behaviours (Newman, 2003; Clarke and Newman, 1997; Dorte Salskov-Iversen, 1999). As Barry et al. (2003) argue NPM is a "contested terrain" on which a reconfiguration of management-professional relations has been "forged". Child welfare professionals are being asked to bridge public and market spheres, adopting positions, which at times contradict previous normative relationship between the state and the individual. Here idealized notions of participatory citizenship and democracy are replaced by new understandings and meanings based upon values derived from the market. Variations
Re-organisation of services for children

335 
EOI

26,4

336

in modes of citizenship, structural inequalities and policy and legal frameworks impact significantly on decision-making processes within care planning for looked-after children and their families. (Ellison and Dorthe-Haestback, 1998; Biehal et al., 1996; Dorte Salskov-Iversen 1999; Dwyer, 2002).

Exemplifying this, social work theory and practice in the United Kingdom is shaped by instrumental reason (Houston, 1996; Blaug, 1995). Here centralized state objectives are pursued through managerialism, bureaucracy and regulation. Child and family social work theory and method across Europe is focused primarily on an ecological perspective (Lorenz, 2006; Hellinkxz and Colton, 1998; Munday and Ely, 1996). The framing of practice centrally relies upon the maintenance of relationships between the child, the family (both nuclear and extended) and the community. For looked-after children issues of contact within care planning strategies become vital to well being. Previous research has found that decision-making processes involving child welfare professionals, looked-after children and their families, define not only the process of care planning but also relationships with care planning (Ellison, 2003; Biehal, 1998). The exploration of the care planning process is theoretically grounded in the work of Habermas (1987) and Goffman (1974). Here, Habermas' work on the emancipation of action from bureaucratic tendencies provides a useful theoretical frame. Assumptions about gendered relations and the way in which children should be socialized are explored. This exploration is theoretically grounded within primary frames for making sense of social life (Goffman, 1974). The connectivities between primary frames and models of citizenship within different welfare settings are explored. The centrality of human relationships within the care planning process has been acknowledged (Webb, 2001; Gilligan, 2000; O’Kane, 1998).

Previous research has demonstrated the constraining effects of NPM on social work practice (Egelund, 1996). These findings have centred upon the elevation of administrative competence over therapeutic effectiveness. Perceptions and experiences of these processes by children and families have been explored in previous research. O'Kane (1998) found that children identified the social service system as inflexible and controlling and described their ideal social worker as caring and understanding. Meanings, perceptions and understandings implicitly define the lived experiences of looked-after children and their families. When we consider NPM as forged within a contested terrains we are reminded of the specificities of national welfare settings in Europe. This paper is concerned to unravel and illuminate the way in which these specificities influence forms of NPM within professional child care social work and practice environments. Before doing so, however, the implications of the reorganisation of child welfare services in Europe particularly in relation to child care law and gender equality will be explored.

\section{Forging NPM, national settings and the reorganisation of child welfare services in Europe}

As social services modernize in many EU Member States, often in partnership with the private sector and non-profit organisations, all involved need clarification on how European law affects this evolving situation. Recent communications from the European Commission suggest a growing awareness of the speed at which transformations are occurring.

... social services of general interest have specific characteristics ... These characteristics include the services being personalized and their aims directly connected with access to fundamental social rights and to the achievement of social cohesion. To reach those aims, 
social services of general interest are based on solidarity ... They also need to be developed as closely as possible to the users (EC, 2006).

The European Commissions communique above is premised upon the notion that welfare services are instrumental to fundamental social rights and social cohesion. The exploration of forms of governance by local authorities and nation states requires a well-grounded conception of public spheres. The analysis of the relationship between gender, new managerialism, identities and ethics within diverging organisational and legal settings is theorized within a framework which views power as being differentiated by gendered institutional barriers and labour processes (Fraser, 1992, 1997; Johnson, 2001; Meehan, 1995; Young, 1996, 2000). Locating this within a broader conceptual framework the reconceptualisation of public and private spheres within feminist theory has promoted gender equality as a normative ideal, which the European Commission regards as being achieved when:

The different behaviour, aspirations and needs of women and men are equally valued and favoured and do not give rise to different consequences that reinforce inequalities (EC, 2005).

Welfare regimes in Europe differ in their articulations of notions of gender and citizenship which in turn operationalise processes of the inclusion and exclusion of women as citizens, workers and parents (Hobson et al., 2002). In the UK, Germany and the Netherlands the strong breadwinner model still predominates (Lewis, 1992), whilst France, Belgium and other continental countries have a tradition of women working full time (Duane-Righard, 2000). Scandinavian countries adopt a dual breadwinner or dual earner model (Korpi, 2000). In Denmark this is enhanced within the public sector by the process of dual socialization, the notion that the state is as responsible as the parent for the upbringing of the child. As the case study evidence below reveals, this model becomes intrinsically important to the analyses of social work practice, and the experience of social work professionals in the UK and Denmark. Significantly, in Denmark continuity planning for looked-after children is contextualized within decision-making strategies founded upon notions of dualsocialization. This strategy is given legal sanction within child care law, by virtue of a series of rights given to parents and children within decision-making processes (Betaenkning 1212, 1990). Social work Professionals work within a system of governance, at local and national level, based upon a conceptualization of citizenship characterized by dual socialization. Adequate levels of resources within a broad spectrum of placement provision for looked-after children (Ellison and DortheHestbaek, 1998; Mehlbye, 1993) bring coherence to social work practice enabling the development of more effective broad based preventative and therapeutic strategies. Danish social work professionals interviewed in this research articulated professional identities and ethics congruent with social work theory and methodological approaches:

For me working within a team is important. I had a case recently where a mother was worried that her whole family would "drowned" unless her sons' relationship was made well again. I was worried about this but I can't decide what the problems are here, we cannot say for a family what their problems are, it is for them to tell us, that is where we begin as professionals. (A Danish Pedagogue)

In contrast, contested terrains within the UK were found to be predicated on broader contradictions within the public sphere. The gendered nature of social justice and citizenship in the UK and the focus on parental responsibility usually defined as the
Re-organisation of services for children 
EOI

26,4

338

responsibility of the mother in the UK (Lister, 2006; Baines, 2004). When combined with resource constraints this created a context within which social work professionals felt frustrated and unable to express their professional and personal identity and ethics (Ellison, 2004).

It's always a very difficult question when you've got siblings because obviously your heart tells you that children should remain in contact at least with their brothers and sisters, if nothing else. The boys were eventually adopted, I felt ashamed about this it's just that there are no placements so there are no choices really we are tied. My heart went out to the mother I felt I had failed her but it was the system that failed her not me. It's not the way in should be. I wasn't trained for this (English Social Worker).

The way in which citizens and welfare professionals have responded to the challenge of a redefined welfare state and the way in which different member states have defended previous notions of citizenship, gender and that which constitutes the social are central to the understanding of "contested terrains" within public welfare in Europe. Illustrating this, Lorenz (2001) has argued that "activism" within the social work profession in Europe has been characterized by the resistance to being incorporated into new social policy agendas. The new practical and political effects of the neo-liberal agenda are also being modified by challenges from welfare cultures and resistance by welfare professionals and user groups (Lorenz, 2001; Andersen and Guillemard, 2006). Here, the relationship between state and citizen is involves interrelated and complex variables. A broader understanding of this relationship acknowledges issues of social rights of citizens (Turner, 1993; Barbalet, 1988; Lorenz, 2001). As Rummery (2006) points out:

The way in which citizens gain access to resources to meet their needs, the way in which they participate (or do not) in the governance of welfare partnerships, and the way in which relations between individuals, communities and the state are affected by welfare partnerships are crucial questions not just for the governance of welfare, but need addressing in order to understand the role of citizenship in the welfare state (Rummery, 2006, p. 223).

\section{NPM, continuities and discontinuities in the UK}

Continuity as a concept is centrally embedded in social work theory across European States and is recognized as an important prerequisite for successful casework (Ellison, 2003; Fanshel, 1990; Lewis and Karen, 1990; Trisilliotis, 1991) Attempts to defend continuity as integral to care work are articulated at different levels. In this sense social work professionals act to abridge public and private need for continuity and in a broad sense modify the practical and political effect of neo-liberal agendas. In Britain, an element of this agenda is embodied in New Labours' emergent social investment state involving policies, which simultaneously invest in children and regulate them and their parents/mothers. Placing children at the heart of social policy is to be applauded; their location within the context of social investment has invoked disquiet as Ruth Lister argues:

... the construction of children as "becomings" rather than "beings"; the paid-work-focused and future-oriented model of citizenship; the relative neglect of groups of children who are not seen to represent such a good investment; and the eclipse of parents', and in particular, mothers' welfare' (Lister, 2006, p. 8).

As has been argued, in Britain childcare policy operationalises notions of citizenship based upon a future orientated labour market participation. Operating within this context social work professionals are at once faced with a public and private domain 
permeated with principles of gendered social justice. Here continuity for the children as "beings" is lost within the quest to ensure that children are neatly fitted into the future orientated model of citizenship, the mothers' welfare is seen as secondary to this (Lister, 2006). Correspondingly the transition from NPM in the 1990s with its focus on efficiency, organisational change, and fragmentation to Progressive Management characterized by effectiveness, joined up partnership working and regulation was given continuity by New Labours' mission to:

... transform nation and people to fit them for a globalised world requiring workforce flexibility,

business deregulation and the modernization of the welfare state (Newman, 2003 p. 26).

The restructuring of the child welfare services in the UK has been the process of redefining the workforce and user groups (Farnsworth, 2006; Du Gay, 1996). Care planning processes have been subjected to disciplinary technologies, which characterize NPM. These technologies are designed to inculcate new values, attitudes, self-understandings and priorities among professionals (Clarke and Newman, 1997; Du Gay, 1996). Parton (1998) has argued that social work in England emphasizes blame instead of trust, efficiency instead of values and control over discretion. Assuming the role of good parent the state then stets out to beaurocratise social work practice. Fragmented care planning emerges when changes in placements or social workers are imposed by administrative requirements (Ellison, 2004). Continuity within care planning is undermined by the absence of consistent one to one relationships between individual social workers and children and their families. The recent fusion of the market and the public sector reform in England has led to the introduction of the notion of "The Corporate Parent". Here, it may be argued that the stigmatization of the birth parents of looked-after children is complete and child welfare social workers are being encouraged to move on from beaurocratic parenting to market driven corporate parenting.

Arguably, the implications of NPM for practice are most usefully explored through the lenses of service users and professionals. The case shown below was very typical of the cases studied during this research particularly in relation to mothers feeling disempowered by the procedural and legal nature of care planning within England.

\section{English case study \\ Background}

The following case study involved a single parent (mother) and her two children Sam, aged 12 and Jenny aged 7 . Following a referral made by the primary school attended the children were taken into care on an Intermediate Care Order and reason for entry was cited as neglect. Following a case conference it was decided that the children would be placed into foster care until such time as they could be re-habilitated with their mother. The main issues raised at the case conference were related to the developmental issues, the children appeared malnourished and their clothes were often dirty. The family lived in an area of social deprivation and the mother was suffering extreme financial difficulties at the time of this interview. All names within this interview have been anonymised.

They just wanted to justify taking the children; they weren't interested in my problems as soon as I mentioned money they seemed to switch off. My social worker keeps telling me I have options, I don't understand what she is on about. I remember they asked me if I wanted them to have the MMR I said no, there's this autism thing isn't there one of my friends told me she regretted it her son has autism and I don't trust the government - anyway they went
Re-organisation of services for children 
EOI

26,4

340

ahead and gave them the injection. Susan said that 'the department was doing what was best for them but I am their mother I love them, but she doesn't know how to care she just knows how to read things off paper and tick boxes, there's no time. It doesn't mean anything to me and I think she knows that but she just carries on anyway. I am not part of anything she is part of everything. She asked me to sign something to say I had agreed with the care plan for Jenny and Sam but when I refused she said it didn't matter anyway there was a court order. And they were going for adoption. Jenny and Sam would have to be split up because no one was willing to take them both. Sometimes I just sit and sit and hold my baby and cry and cry and cry I don't want to lose him as well .... If I could just get someone to listen to me ... Things would be easier for me if I had enough money to live on, I think things would get better then. I do want to look after my kids the way they should be looked-after I just need some support some money and somewhere away from here ... I know I let things go a bit, I got really down. It's like all my energy goes into just staying afloat. I find it hard to think sometimes (Mother, England).

For this mother, the care planning process was a dis-empowering experience. Here, experience of the care planning process defined by individuation, fragmentation' and disconnectedness (Clarke, 2006). Clearly each case is unique and complex, however, when we analyse this discourse more closely blockages are found to be linked with the process of NPM itself. The care planning process is a disempowering experience for this mother there is "no time, it doesn't mean anything just seem to tick off boxes". Here, blockages within the care planning process become resistance taking the form of action "so I refused to sign". This resistance is almost immediately counterposed by the use of legal instruments of the state; "but when I refused she said it didn't matter anyway there was a court order". Moreover this discourse relates to broader contextual factors "I have failed as a mother I don't have any rights any more". Here rights are defined within a primary frame defined within a social investment state (Lister, 2006). Gendered notions of citizenship are drawn upon within this mother's interpretation of rights. Any vestige of "power" or "voice" within the care planning processes is erased by her "failure" as a mother. In terms of social work methodology, person-centered and ecological approaches are usurped by beaurocratic and legally defined administrative mechanisms. Here, consideration for human relationships seems to have been abandoned. "They start asking me questions and I can't think I need more time I need someone to listen”. Trust has broken down between the professional and user and indeed between the user and the state; "I don't trust this government", decision-making processes here are limited by the use of the court order, power within care planning is legally defined by state instruments. It may be argued that partnership as conceptualized within the Children Act (1994) England and Wales, ultimately relies on trust and this takes time and careful listening (Biehal, 1998). The imperatives of the market and NPM act to limit time. The Bureaucratic and fragmented nature of NPM restricts relationships between professionals and users within the caring sphere (Baine, 2005). Here, the mother reflects on her own identity as a mother;

Susan (the social worker in this case) said that 'the department was doing what was best for them but I am their mother I love them, but she doesn't know how to care she just knows how to read things off paper and tick boxes.

This identity is imbued with her caring role and immediately contrasted with the bureaucratic role played by the social worker in this case. Self-awareness and understanding of the import of NPM on the care planning process and indeed on the 
caring role itself is almost immediately undermined when she says; I sometimes think its me. "It's because I have failed as a mother I don't really have any rights anymore".

Here, she assumes that she must take full responsibility for her children's situation. She has failed as a mother and this is intrinsically linked to her rights as a mother. Ruth Lister argues that gendered citizenship permeates public and private understandings of issues and relationships within child welfare policy and practice. For this mother blockages and resistances are defined by her own self-awareness of her relationship with her children and her perception of social services as being inferior and inappropriate. At the same time, the responsibility and self-blame she bears is framed by a broader societal context, which is characterized by gendered citizenship located within a "surveillance society" (Lorenz, 2006). Crucially, however, blockages are transposed into resistance as action when the mother refuses to sign the care plan. Once again, however, contextual limitations render this resistance pointless as legal instruments are used to override this action.

... when I refused she said it didn't matter anyway there was a court order. And they were going for adoption. Jenny and would have to be split up because no one was willing to take them both.

Time is intrinsic to person-centred theory and methodology within social work. Here, partnership within the care planning process relies not only upon the ability of the user to define their own problems in their own way (Biehal, 1998) but also upon being given the time to do so. As Garrett (2002) illustrates, the marketisation of child and family welfare services in the UK is also reflected by references to the "stock" of children in public care, (PIU, 2000, p. 19, 86).

The utilization of the language of the market serves to degrade, over-simplify and aggregate the unique set of circumstances that have led children into public care, managerialist and target oriented time saving directives manipulate care planning process denying the possibility of person-centered social work practice (Garrett, 2002, p. 28).

This observation is reinforced by other research (Taylor-Gooby, 2000; Clarke and Newman, 1997; Powell, 1999). The marginalization of birth parents and birth families Within New Labour's discourse is located within an ideological approach to child welfare, which utilises specific constructs of parenting. As the extract above shows failure to "listen to" or enable mothers of looked-after children to feel "part of any thing" can be seen in part to reflect the broader malaise of New Labours social investment state. Here, policies are designed to invest in children whilst regulating them and their parents/mothers (Lister, 2006). A model of citizenship, which allows:

The relative neglect of groups of children who are not seen to represent such a good investment; and the eclipse of parents, and in particular, mothers' welfare (Lister, 2006).

It may be argued that child and family welfare services are an inappropriate setting for the introduction of market derived organisational and management paradigms. Contextual limitations arise not simply from the bureaucratic, and mechanistic characteristics of NPM but also from resource constraints. These constraints emerge from social and economic inequalities arising from the conduct of the market itself. Social work theory, methodology and practice is filtered here by situational constraints arising from such inequalities. When placed into European context, it is evident that the blueprint which has formed the bases of the marketisation of child care within the UK has been adopted by other European Societies. Exemplifying this, Sweden has very
Re-organisation of services for children 
EOI

26,4

342 recently begun to pilot a new organisational framework for the delivery of services for vulnerable children.

\section{Exploring connectivities in Sweden and Denmark}

The contours of governance, citizenship and NPM. The implementation of NPM within child welfare services in Denmark and Sweden has been located within welfare values, which approve the central role of the state as guarantor of equality and social solidarity. This distinct model of welfare capitalism emphasizes citizens' right to public social welfare and tries to prevent rather than just meet welfare needs. Here, child welfare policies are guided by the principle of equality rather than by a needs bases ideology (Dorte Salskov-Iversen, 1999; Johansson and Jansson, 1998; Mehlbye, 1993; Egeland, 1997).

In Denmark broader social policy initiatives have led to activation policies that have channelled substantial investment into individualised social work support for welfare recipients (Lorenz, 2006). Considerable emphasis is placed on service provision in addition to financial transfers within child welfare. This integrated approach is a key feature of children and family policies and prevention strategies. The Danish welfare state is also characterized by the way it has embraced and supported increasing levels of economic activity rates for women. Many social and economic activities, which were previously performed within the family by women, are now undertaken within the formal sector. The lived experiences of individuals as welfare users and citizens are shaped by the Danish State's strong social equality goal and continued commitment to universal benefits ensuring the rights of children and their families to particular benefits and services (Mehlbye, 1993; Lorenz, 2006). Child care law in Denmark reflects these central tenets (Ellison and Dorthe-Hestbaek, 1998). The Social Services Act regulates social services and emphasizes the users' right to influence. In recent years, Danish social policy has changed with increasing emphasis on decentralized responsibility for policy implementation. The decentralization of social policy started in the 1980s, when a number of social institutions were transferred from the state to the counties. Subsequently, there has been further decentralization from counties to local authorities. Similarly the Social Services Act (Socialtjanstlagen) (2002) has secured the general aims and "fundamental democratic principles of Social Services in Sweden".

In common with Denmark, Swedish child welfare emphasizes prevention and early intervention. The "integrity" of the biological family is central to assessment driven intervention. (Mehlbye, 1993; Lorenz, 2006; Ellison, 2004). This contrasts sharply with the England where adversarial legal approaches and an emphasis on child protection and permanency planning marginalizes biological parents and restricts eligibility to a limited range of services to the most needy children. The impact of these contrasting approaches is most telling when decision-making processes within care planning for looked-after children are explored. In Sweden, The Social Services Act (2002) "frames law", regulating several areas of social support and interventions: economic assistance, preschool child care, and child welfare. Thus:

All services provided under the Social Services Act are based on free choice and autonomy" These services must be adapted to your individual circumstances and your desire to change your social situation .... If you do not receive the support and assistance you want and have requested, you may appeal the municipal authorities decision (Socialtjanstlagen, 2002, p.2; Socialstyrelsen and Artikelnr, 2002, pp. 114-9).

State subsidised childcare provision is pivotal to dual socialisation and gender equality in Sweden. Whilst it must be noted that in recent years this area has been subjected to 
reductions in subsidy rates (Bjdrnstrom, 1996), Swedish child welfare policy and practice still emphasizes social support and prevention rather than child protection (Clausen, 1998; Jonassen et al., 1997). Critically the impact of global market forces has been filtered by the designation of child welfare as a protected area within local governance. Local child welfare became a "protected zone" and financial resources have remained intact or are growing (Socialstyrelsen, 1994a, b; 1998a, b; Bergmark, 1995). Recent research has shown that the voluntary sector still retains an important function within child welfare delivery despite the state retaining overall responsibility. A central characteristic of practice with looked-after children and their families in Sweden is the utilisation of "family treatment" and "family support" (Socialstyrelsen, 1998a,b). In common with Denmark social pedagogues are still frequently used as "Family educators". In Denmark and Sweden social pedagogues provide advice, support, skills training of parents and give practical help, often for several years in the same family. These highly resource-intensive forms of intervention still predominate within child and family social work practice and clinical individual and family therapy for children and families remain a standard tool in child welfare practice in Denmark and Sweden (Ellison and Dorthe-Heastback 1998; Jonassen et al., 1997).

Recent attempts to impose NPM within child welfare services in Sweden and Denmark have been filtered by a citizenship model, which emphasizes rights and gender equality, and also by historical and cultural factors, which impact heavily on organisation and governance. In Sweden, the welfare system emerged from strong popular movements. As in Denmark, the welfare system in Sweden has always been decentralized, with a range of services contracted out. Recent changes in social policy have introduced many quasi- and actual-market conditions into the social service delivery system while still assigning overall responsibility for the setting of standards to the state. (Jonassen et al., 1997; Lorenz, 2006) Citizens are concerned about inequalities arising from market conditions but their concerns are negotiated at both the political and the market level (Lundstrom and Wejkstrom, 1997). As the evidence below illustrates whilst the presence of social democratic citizenship models, dual socialisation, redistributive fiscal systems and an emphasis on gender equality do go some way towards filtering the process of marketisation within Denmark and Sweden, recent incursions into the field of professional child care social work practice have led to blockages from professionals themselves. Here, the introduction of ways of working that are incongruous with existing, theoretical, methodological and ethical meanings and identities has led to an unwillingness amongst social workers to apply NPM.

The imposition of NPM in Sweden. The recently piloted Child in Focus System in Sweden is based upon the Integrated Child Care System in England and Wales. As the extract below shows, the "autonomy" of social workers to act according to their own professional and personal understandings, values and ethics is being challenged by the imposition of NPM. The blockages that emerge are indicative of broader concerns, which relate to the voice and power of professionals and user groups within Sweden. More broadly as mediators of the relationship between the state and the citizen (Lorenz, 2006) the implications of these incursions and blockages may tell us more about the impact of marketisation on child welfare services than incursions at the level of policy. Exemplifying this recent pilot research carried out in Sweden involved interviews with social work professionals at different levels reveals the emergence of blockages when NPM is implemented at the level of practice. Frustrated at slowness of implementation and acceptance of NPM a social work manager articulates her
Re-organisation of services for children

343 
EOI

26,4

\section{4}

frustration at the way in which social work practitioners are blocking the implementation of NPM within social work practice.

Social workers in this municipality are very conservative, In the 1980s social work theory was based on action it was not necessary to record everything. In the 1990s there were a lot of audits and economic problems there was a backlash it was recognized that there was a need to document everything for social workers to be made more accountable for their time. It is about transparency, in the 1970s and 1980s the board of social security decided about compulsory placements now it is the court if you go to court you have to be precise and use another language. You know we may ask a family the question 'do you think you need help, and if we don't get an answer we can say and record well we think you need help'. It is more legal that way it makes us more accountable, Children's needs in Focus is a way of thinking. We are not just focusing on the problem we are looking at ways of finding solutions by carefully documenting and assessing the child's situation, look at the strengths and weaknesses of the parents the community factors and the children's needs its about prevention you see and all of this has to be carefully documented first in a standardized way (Swedish Social Services Manager).

Here, the centrality of professional autonomy is revealed as being fundamental to existing professional identities.

They want to decide for themselves how to work because they work so independently they don't want to be told how to work because they want to decide for themselves how will I do my work in my way in the old way (Swedish Social Services Manager).

Moreover, "Time" and therapy are identified as intrinsic to the "old way" of working; "Social work paradigms were concentrating on therapy and it was more important to spend time talking to people"

Many of our social workers here are still locked into old methods they just want to spend time talking with families and children they keep saying if we don't get more money we can't work in this new way. It is not just about resources though it is about designing more efficient ways of working (Swedish Social Services Manager).

In identifying resources as a key issue it may be argued that practitioners are showing concern that person centred and ecological approaches to practice may become limited by a more service led agenda. This concern has resonance in Denmark.

Denmark, filtering the imposition of NPM. As has been shown the Danish welfare state is also characterized by the way it has embraced and supported increasing levels of economic activity rates for women. Many social and economic activities, which were previously performed within the family by women, are now undertaken within the formal sector. Decentralized forms of governance and dual-socialisation in Denmark facilitate the development of innovatory forms of practice. As the case study evidence below demonstrates these processes filter the implementation of NPM within child welfare settings, by legitimating and strengthening more innovative practice approaches. Critical to legitimation, the lived experiences of individuals as welfare users and citizens are shaped by the Danish State's strong social equality goal and continued commitment to universal benefits to ensure the rights of children and their families to particular benefits and services. (Lorenz, 2006) Child Care Law in Denmark reflects these central tenets (Ellison and Dorthe-Hestbaeck, 1998). The Social Services Act regulates social services and emphasizes the users' right to influence. In recent years, Danish social policy has changed with increasing emphasis on decentralized responsibility for policy implementation. As the extract below illustrates the marketisation of child welfare services is filtered by the devolution of governance. 
At the moment this municipality retains 35 residential institutions, which hold a total of 800 places. We believe it is important to retain such provision as part of a broad range of out of home placements, however, we are also concerned to make our ideas of prevention work. Part of this is about helping children to stay in close contact with families. This is their legal right and we are responsible for the welfare of these families. We have therefore made some recent advances in practice in our day treatment centres such as the Solbakken Centre, Centres such as this allow children and parents to receive family treatment or skill programmes during the day and to remain together in their home. If such programmes fail in individual cases it may be that an out of home placement is sought for children. It is true that day treatment centres are less costly than residential or professional foster placements, however, we are not prepared to reduce our residential provision because it is recognized here that a range of provision is always necessary in order that planning can (I am not sure how to say it in English) fit? individual needs of children during the whole time of their care plan. Just yesterday we received a circular (circular nr. 203af 26.Docialministeriets) from the Ministry of Social Affairs in relation to day treatment centres emphasizing their importance in maintaining family network. We have recently been under a lot of pressure to bring the costs down we are trying to increase the number of day treatment centres that we have and make them suitable for families with more intensive needs for therapy if you have a range of specialist centres then and only then can we begin to close residential centres. We have said that we will try to bring down costs but not at the expense of our provision (Director of Social Services with a Danish Municipality).

The emergence of resistance at organisational level is triggered here by calls from the Ministry of Social Affairs to reduce the cost of provision.

The ability of the Director of social services at this municipality to develop innovative provision is reliant upon the existence of rights led policy and legal frameworks and a model of citizenship which is based upon notions of dual socialization. Decentralized governance in Denmark allows local policy makers a good deal of autonomy. In this extract, reference is made to the legal rights of children and families and the responsibility of the social service, provision and practice is contextualized within a strongly preventative approach. The pressures exerted by marketisation and NPM are filtered by an approach, that gives primacy to the needs of families and their children. The local municipality is given time and space to reorganise provision according to these principles.

We have recently been under a lot of pressure to bring the costs down we are trying to increase the number of day treatment centres that we have and make them suitable for families with more intensive needs for therapy if you have a range of specialist centres then and only then can we begin to close residential centers (Director of Social Services with a Danish Municipality).

\section{Conclusion}

This paper has sought to explore the relationship between Gender, NPM, citizenship and professional and user group relationships and identities within child care social work practice. Welfare regimes in Europe differ in their articulations of notions of gender and citizenship, which in turn operationalise processes of the inclusion and exclusion of women as citizens, workers and parents (Hobson et al., 2002). This has led to the loss of continuity in relation to past welfare provision and implied notions of social rights. This change of regime and loss of continuity has given rise to forms of blockages and resistances to the imposition of forms of NPM within different welfare contexts. Here, the relationships between professionals and user groups is found to be as much a question of citizenship models and the embedding of notions of gender
Re-organisation of services for children 
EOI

26,4

346 equality within state-societal relationships as it is of the professional commitment of social workers as individuals. Indeed the illustrations used in this paper point to the constraining effects of NPM within professional child care social work practice. The concept of continuity unifies principles of childcare social work practice in Europe. Here holistic approaches rely upon the operationalisation of principles of partnership within social work practice. As the extracts illustrate NPM within these distinct settings is perceived and experienced by user's and social work professionals as being an impediment to the achievement of these principles. For the mother in England technical devices and instruments used within the care planning process left her feeling disempowered within a fragmented and meaningless process. For her there was "no time" and no one was really "listening". In Sweden, social work professionals are concerned by the imposition of NPM for many of the same reasons as the mother describes in England. Here, social work theory and methodological approaches recognize the intrinsic value of approaches which give people time to talk. In Denmark, the value of decentralized forms of governance is revealed as the Director of Social Services in a local municipality uses innovatory forms of provision to filter reductions in available funding. This paper has found that assumptions about gendered relations and the way in which children should be socialized are intrinsic to decision-making processes within care planning for looked-after children and their families. In Britain gendered notions of citizenship (Lister, 2006) mitigate against holistic approaches within child care social work practice. Here, mothers are marginal to child welfare interventions as children are conceptualized in terms of their future worth as social investments rather than as current social beings. In contrast, in Denmark and Sweden principles of dual socialisation strengthen the rights of user groups and particularly women and enable the operationalisation of more effective forms of partnership within care planning processes. Finally, this paper has identified the need to do further comparative research on the implications of NPM on child and family centred practice within Europe. Whilst acknowledging the unique and complex nature of cases it is argued that fundamental processes underpinning care planning are compromised by market incursions into this and other spheres of social work practice. Framed through the lenses of constructions of citizenship and rights, new forms of analysis are required within these emerging organizational, governmental and legal frameworks. The identification and dynamics of blockages and resistances articulated by welfare professionals and user groups can prove to be one valuable form. Analytical clarity requires that the exploration of these processes is grounded in an investigative methodology which is multilayered and interdisciplinary. The import of this research is to inform professional social work practice and to encourage the legitimate framing and activation of public policies, which promote equality, empowerment and social rights within European welfare regimes.

\section{References}

Andersen, J.G. and Guillemard, A.-M. (2006), "Policy change, welfare regimes and active citizenship" in Andersen, J.G., Guillemard, A., Jensen, P.H. and Effinger, B.P. (Eds), The Changing Face of Welfare, The Policy Press, Bristol.

Andersson, G. (1995), Barn i samhallsvard [Children in public care], Studentlitteratur, Lund.

Betaenkning (1212), (1990), Betaenkning om de retige rammer for indsatsen overfor boern og unge (On the legal framework for efforts to support children, Danish Ministry of Social Affairs Publication, Copenhagen. 
Baines, D. (2004), "Pro-market, non-market: the dual nature of organizational change in social services delivery critical social policy”, Critical Social Policy, Vol. 24 No. 1, pp. 5-29.

Barry, J., Dent, M., and O'Neil, M. (2003), Gender and The Public Sector, Professions and Managerial Change, Routledge, London.

Beresford, P. (2005), "Redistributing profit and loss: the new economics of the market and social welfare", Critical Social Policy, Vol. 25, pp. 464-82.

Bergmark, A. (1995), Prioriteringar i socialtjansten [Priorities of Social Services], inst for socialt arbete, Rapport i socialt arbetc, Stockholms Universitet.

Biehal, N.N., Fisher, M., Marsh, P. and Sainsbury, E. (1996), "Rights and social work in the welfare of citizens", in Coote A. (Ed.), The Welfare of Citizens, River Oram Press, London.

Blaug, R. (1995), "Distortion of the face-to-face: communicative reason and social work practice." British Journal of Social Work, Vol. 25, pp. 423-39.

Born, A.W. and Jensen, P.H. (2005), "Individualising citizenship" in Andersen, J.G., Guillemard, A., Jensen, P.H. and Effinger, B.P. (Eds), The Changing Face of Welfare, The Policy Press, Bristol.

Clarke, J. (2004), "Dissolving the public realm? The logics and limits of neo-liberalism”, Journal of Social Policy, Vol. 33 No. 1, pp. 27-48.

Clarke, J. (2005), “New Labour's citizens: activated, empowered, responsibilized, abandoned?”, Critical Social Policy, Vol. 25, pp. 447-63.

Clarke, K. (2006), "Childhood, parenting and early intervention: a critical examination of the Sure Start national programme”, Critical Social Policy, Vol. 26, pp. 699-721.

Clarke, J. and Newman, J. (1997), The Managerial State: Power, Politics and Ideology in the Remaking of Social Welfare, Sage, London.

Deacon, B. (2001), "International organisations, the EU and global social policy", in Sykes, R., Palier and Prior, P. (Eds), Globalisation and European Welfare States: Challenges and Change, Palgrave, Basingstoke.

Dorte S.-I. (1999), Clients, Consumers or Citizens? Cascading Discourses on the Users of Welfare, Staffordshire University Press, Stoke on Trent.

Dwyer, P. (2002), "Making sense of social citizenship: some user views on welfare rights and responsibilities", Critical Social Policy, Vol. 22, pp. 273-99.

EC (2005), Equality between women and men. European Commission, Directorate-General for Employment, Social Affairs and Equal Opportunities Unit G1: August 2005.

EC (2006), European Commission Press Release IP/06/529:MEMO 06/170:COM (2 May 2006)177 final - Implementing the Community Lisbon Programme: Social Services of General Interest in the European Union.

Egelund, T. (1996), "Bureuacracy or professionalism? The work of child protection services. Scandinavian", Journal of Social Work, Vol. 5, pp. 165-74.

Ellison, N. (1999), "Beyond universalism and particularism: rethinking contemporary welfare theory" Critical Social Policy, Vol. 19, pp. 57-85.

Ellison, M. (2000), "Looked after children and their families: issues for social exclusion and practice", children, social exclusion and citizenship. Policy and practice for children who are socially excluded in Denmark and the UK Conference, Sunderland University, November 2000.

Ellison, M. (2003), "Post new public governance and health and social care services for lookedafter children and their families in england and denmark", in Radcliffe, J. et al. (Eds), Dilemmas for Human Services, University of Staffordshire, Stoke on Trent.

Ellison, M. (2004), "Delivering continuity for European siblings in care, visions prospects and possibilities for child and family law, practice and health and social care policy within denmark and the UK”, in Chandler, J. and Barry, J. (Eds), Dilemmas Facing the Public
Re-organisation of services for children 
EOI

26,4

348

Sector: Issues for Professionals, Managers and Users, University of East London Publications, London.

Ellison, M. and Dorthe-Hestbaek, A. (1998), Working Together, Turning Legal Principles into Practice: the Case of the UK and Denmark, in Exchanging Visions: Best Practice in Europe for Children Separated from Their Birth Parents, BAAF.

Every Child Matters Green Paper (2003), HMSO, London.

Fanshel, D., Finch, S.J. and Grundy, J.F. (1990), Foster Children in a Life Course Perspective, Columbia University Press, New York, NY.

Farnsworth, K. (2006),“Capital to the rescue? New Labour's business solutions to old welfare problems”, Critical Social Policy, Vol. 26, pp. 817-42.

Garratt, P.M. (2002), "Encounters in the new welfare domains of the Third Way: social work, the Connexions agency and personal advisers”, Critical Social Policy, Vol. 22, pp. 596-618.

Garrett, P.M. (2002), “Getting 'a grip': New Labour and the reform of the law on child adoption”, Critical Social Policy, Vol. 22, pp. 174-202.

Gender Equality Consolidation Act (2002), Danish Ministry of Social Affairs.

Gilligan, R. (2000), "The key role of social workers in promoting the well-being of children in state care - A neglected dimension of reforming policies”, Children and Society, Vol. 14, pp. 267-76.

Goffman, E. (1974), Frame Analysis: An Essay on the Organisation of Experience, Harper Colophon, New York, NY.

Habermas, J. (1987), The Theory of Communicative Action. Volume 2: System and Lifeworld: A Critique of Functionalist Reason, Polity Press, London.

Harding, L.F. (1991), Perspectives in Child Care Policy, Longman, London.

Harvey, D. (2005), A Brief History of Neo-Liberalism, Oxford University Press, Oxford.

Hellinkxz, W. and Colton, M. (1998), "International perspectives in family support", Arena.

Houston, S. (1996), Setting Quality Standards for Social Work Practice in Residential Child Care: A Collaborative Approach, Eastern Health \& Social Services Board, Belfast.

Jack, G. (2000), "Ecological influences on parenting and child development", British Journal of Social Work, Vol. 30, pp. 703-20.

Johansson, S. and Jansson, M. (1998), "Vocabularies of citizenship and gender: Sweden”, Critical Social Policy, Vol. 18, pp. 397-415.

Kooiman, J. (Ed.) (1993), Modern Governance: Government Society Interactions, Sage, London.

Larsen, J.E. (2005), "The active society and activation policy: ideologies, contexts and effects", in Andersen, J.G., Guillemard, A., Jensen P.H. and Effinger, B.P. (Eds), The Changing Face of Welfare, The Policy Press, Bristol.

Lewis, A. (1992), "An overview of research", in Thoburn, J. (Ed), Participation in Practice: A Reader, UEA, Norwich.

Lewis, K. and Karen, G. (1990), "Siblings a hidden resource in therapy", Journal of Strategic and Systemic Therapies, Vol. 9, pp. 39-49.

Lister, R. (2006), "Children (but not women) first: New Labour, child welfare and gender", Critical Social Policy, Vol. 26, pp. 315-35.

Lorenz, W. (2001), "Social work responses to new labour in continental european countries", British Journal of Social Work, Vol. 31, pp. 595-609.

Lorenz, W. (2006), Perspectives on European Social Work: From the Birth of the Nation State to the Impact of Globalisation, Intl Specialized Book Service Inc., Portland.

Mehlbye, J. (1993), "Denmark" in Colton, M.J. and Hellinckxs, W. (Eds), Child Care in the EC, Arena, Hants. 
Mishra, R. (1999), The Welfare State in Capitalist Society, Harvester/Wheatsheaf, Hemel Hempsterd. Mooney, G. and Poole, L. (2004), "A land of milk and honey?" Social policy in Scotland after Devolution”, Critical Social Policy, Vol. 24, pp. 458-83.

Munday, B. and Ely, P. (Eds) (1996), Social Care in Europe, Prentice Hall, Englewood Cliffs, NJ.

Navarro, V. (1998), "Neo liberalism, globalization, unemployment, inequalities and the welfare State", International Journal of Health Services, Vol. 28 No. 4, pp. 607-82.

Newman, J. (2003), "From new managerialism to progressive governance? new leadership values, choices and dilemmas", for the 7th International Research Conference dilemmas for Human Services, Staffordshire University, Stoke on Trent.

Offe, C. (1996), Modernity and the State, MIT Press, Cambridge, MA.

Parton, N. (1991), Governing the Family: Child Care, Child Protection and the State, Macmillan, London.

Parton, N. (1998), "Risk, advanced liberalism and child welfare: the need to re-discover uncertainty and ambiguity", British Journal of Social Work, Vol. 28, pp. 5-28.

Pugh, R. and Gould, N. (2000), "Globalisation, social work, and social welfare", European Journal of Social Work, Vol. 3 No. 2 pp. 123-38.

Rhodes, M. (1996), "Globalization and the West European welfare states: a critical review of recent debates", Journal of European Social Policy, Vol. 6 No. 4, pp. 305-28.

Rummery, K. (2006), "Partnerships and collaborative governance in welfare: the citizenship challenge", Social Policy and Society, Vol. 5 No. 2, pp. 293-303.

Ryburn, M. (1996), "A study of post-adoption contact in compulsory adoptions”, British Journal of Social Work, Vol. 26, Oxford Journals, Oxford.

Saks, M. (1999), "Professions, markets and public responsibility", in Dent et al. (Eds), Professions, New Public Management and the European Welfare State, Staffordshire University Press, Stoke on Trent.

Socialtjanstlagen (2002), Socialtjänstlagen kap, 6, 8, Danish Ministry of Social Affairs.

The Children Act (1994), HMSO, London.

The Children Act (2004), HMSO, London.

The Social Services Act (2002), Danish Ministry of Social Affairs, Copenhagen.

Trisilliotis, J. (1991), Permanency Planning. Perceptiions of permanence. Adoption Fostering, pp. 4, 6-15, BAAF.

Weightman, K. and Weightman, A. (1995), "Never right, never wrong”: child welfare and social work in England and Sweden”, Scandinavial Journal of Social Welfare, Vol. 4, pp. 75-84.

\section{Further reading}

Ashenden, S. (1999), "Habermas on discursive consensus: rethinking the welfare state in the face of cultural pluralism”, in Chamberlayne, P., Cooper, A., Freeman, R., and Rustin, M. (Eds), Welfare and Culture in Europe: Towards a New Paradigm in Social Policy, Jessica Kingsley Publishers, London, pp. 216-39.

Baine et al. (1992), Changing Europe: Challenges Facing the Voluntary and Community Sectors in the 1990's, NCVO Publications, London.

Barth, R. (1992), "Child welfare services in the United States and Sweden: different assumptions, laws and outcomes", Scandinavian Journal of Social Welfare, Vol. 1, pp. 36-42.

Braye, S. and Preston-Shoot, M. (1998), "Social work and the law", in Adams, R., Dominelli, L. and Payne, M. (Eds), Social Work: Themes, Issues and Critical Debates, Macmillan, London.

Clark, A. and Moss, P. (2001), Listening to Young Children: The Mosaic Approach, National Children's Bureau and Joseph Rowntree Foundation.
Re-organisation of services for children 
EOI

26,4

350
Deacon, A. (2000), 'Learning from the US? The influence of American ideas upon 'New Labour' thinking on welfare reform", Policy and Politics, Vol. 28 No. 1, pp. 5-18.

Deacon, A. and Mann, K. (1999), "Agency, modernity and social policy”, Journal of Social Policy, Vol. 28, pp. 413-35.

Dent, M., Chandler, J. and Barry, J. (2004), Questioning the New Public Management, Ashgate Publishing, London.

Department of Health (2000), Framework for the Assessment of Children in Need and Their Families, Her Majesty's Stationery Office, London.

Department of Health (2004), The Children Act (England and Wales), Her Majesty's Stationery Office, London.

Elsley, S. (2006), No Time to Lose: A Manifesto for Children and Young People Looked After Away From Home, The Scottish Institute for Residential Child Care.

Ferguson, H. (2001), "Social work, individualisation and life politics", British Journal of Social Work, Vol. 31, pp. 41-55.

Foucault, M. (1991), "Governmentality”, in Burchell, G., Gordon, C. and Miller, P. (Eds), The Foucault Effect: Studies in Governmentality, Harvester Wheatsheaf, London.

Garrett, P.M. (1999), "Producing the moral citizen: the 'Looking After Children' system and the regulation of children and young people in public care”, Critical Social Policy, Vol. 19, pp. 291-311.

Garret, P.M. (1999), "Mapping child care-social work in the final years of the twentieth century: a critical response to the 'Looking After Children' system”, British Journal of Social Work, Vol. 29, pp. 27-47.

Giddens, A. (1994), "Living in a post-traditional society", in Beck, U., Giddens, A., and Lash, S. (Eds), Reflexive Modernisation: Politics, Tradition and Aesthetics in the Modern Social Order, Polity Press, Cambridge.

Gillies, V. (2005), 'Meeting parents' needs? Discourses of 'support' and 'inclusion' in family policy", Critical Social Policy, Vol. 25, pp. 70-90.

Gustafsson, P. et al. (1993), "Siblings in family therapy”, Journal of Family Therapy, Vol. 17, pp. 317-27.

Habermas, J. (1984), The Theory of Communicative Action. Volume 1: Reason and the Rationalisation of Action, Polity Press, London.

Habermas, J. (1992), "Further reflections on the public sphere", in Calhoun, C. (Ed.), Habermas and the Public Sphere, MIT Press, Cambridge, MA, pp. 421-61.

Habermas, J. (1998), "Struggles for recognition in the democratic state", in Cronin, C. and De Greff, P. (Eds), The Inclusion of the Other, MIT Press, Cambridge, MA, pp. 215-20

Holman, B. (1988), Putting Families First, Macmillan, London.

Humphrey, J. (2003), "New labour and the regulatory reform of social care", Critical Social Policy, Vol. 23, pp. 5-24.

Jordan, B. (1997), "Social work and society", in Davies, M. (Ed.), The Blackwell Companion to Social Work, Blackwell, Oxford.

Jordan, B. (2005), “New labour: choice and values”, Critical Social Policy, Vol. 25, pp. 427-46.

Lister, R. (1998), "From equality to social inclusion: New Labour and the welfare state”, Critical Social Policy, Vol. 18, pp. 215-25.

Lister, R. (2005), Critical Social Policy, Vol. 25, pp. 349-73.

Lorenz, W. (1998), "Children and european social policy traditions", Address to the BAAF and EBU Conference Exchanging Visions Policy, Vol. 26 No. 2, pp. 315-35. 
Lorenz, W. (1999), "Social work and cultural politics: the paradox of German social pedagogy", in Chamberlyne, P., Cooper, A., Freeman, R., and Rustin, M. (Eds), Welfare and Culture in Europe: Towards a New Paradigm in Social Policy, Jessica Kingsley, London.

Ministry of Social Affairs (1992), Social Security Act.

Ministry of Social Affairs (1995), Denmark - National Report World Summit of Social Development-Copenhagen 1995, Jellint Bogtrykkeri.

Ministry of Social Affairs (1997), "Social policy in Denmark", Child and Family Politics, Ministry of Social Affairs, Copenhagen.

Parker, R., Ward, H., Jackson, S., Aldgate, J. and Wedge, P. (Eds) (1991), Looking After Children: Assessing Outcomes in Child Care, HMSO, London.

Payne, M. (2000), Anti-Bureaucratic Social Work, Venture Press, London.

Powell, M. and Hewitt, M. (2002), Welfare State and Welfare Change, Open University Press, Buckingham.

Powell, R. (1998), "Managerial procedure and professional practice in social work", in Hunt, G. (Ed.), Whistleblowing in the Social Services: Public Accountability and Professional Practice, Arnold, London.

Martin, P. (2000), "New Labour and the third way in the British welfare state: a new and distinctive approach?”, Critical Social Policy, Vol. 20, pp. 39-60.

Room, G. (2005), The European Challenge, The Policy Press, Bristol.

Sanderson, H., Kennedy, J., Ritchie, P. and Goodwin, G. (1997), People, Plans and Possibilities: Exploring Person Centred Planning, SHS, Edinburgh.

Scholte, E., Colton, M., Casas, F., Drakeford, M., Roberts, S. and Williams, M. (1999), "Perceptions of stigma and user involvement in child welfare services", British Journal of Social Work, Vol. 29, pp. 373-91.

Scott, G. (1998), "Child-care: the changing boundaries of family, economy and state", Critical Social Policy, Vol. 18, pp. 519-28.

Sinclair, R. (2004), "Participation in practice: making it meaningful, effective and sustainable", Children and Society, Vol. 18 No. 2, pp. 106-18.

Smale, G., Tusan, G., Biehal, N. and Marsh, P. (1993), Empowerment, Assessment, Care Management and the Skilled Worker, HMSO, London.

Spratt, T. and Houston, S. (1999), "Developing critical social work in theory and in practice: child protection and communicative reason", Child and Family Social Work, Vol. 4, pp. 315-24.

Thomas, N. (2002), Children, Family and the State: Decision Making and Child Participation, The Policy Press, London.

Trevellion, S. (1997), "The globalisation of European social work", Social Work in Europe, Vol. 4 No. 1, pp. 1-8.

\section{Corresponding author}

Marion Ellison can be contacted at: Mellison@qmuc.ac.uk

To purchase reprints of this article please e-mail: reprints@emeraldinsight.com Or visit our web site for further details: www.emeraldinsight.com/reprints

Re-organisation of services for children 